\title{
Antibiotic resistance: Microbiological profile of urinary tract infections in Mexico
}

\author{
Resistencia a antibióticos: Perfil microbiológico de las infecciones de vías urinarias en \\ México
}

\section{Erick Sierra-Díaz ${ }^{*}$, Cesar J. Hernández-Ríos ${ }^{1}$ and Alejandro Bravo-Cuellar ${ }^{2}$}

${ }^{1}$ Departamento de Urología, UMAE Hospital de Especialidades Centro Medico Nacional de Occidente; ${ }^{2}$ Departamento de Inmunología, Centro de Investigación Biomédica de Occidente. Instituto Mexicano del Seguro Social, Guadalajara, Jalisco, México

\begin{abstract}
Objective: The objective of this study was to describe the prevalence, microbiological profile, bacterial resistance, and the sensitivity to antibiotics of microorganisms causing urinary tract infection (UTI) at a single-site tertiary referral hospital in the western region of Mexico. Methods: A total of 5895 culture samples processed at the microbiology laboratory from August 1 , 2014, to July 31, 2015, were analyzed. Results: A total of 5895 samples for urine cultures (UC) were collected, of which 3363 were taken in women (57.05\%) and 2532 in men (42.95\%). A prevalence of 24\% was calculated. From 1444 positive UC, 1512 microorganisms were isolated; the major etiological agent was Escherichia coli, representing 67.28\% followed by Pseudomonas with $7.12 \%$. With respect to fungi, Candida glabrata was found as the most common agent. Susceptibility to daptomycin and linezolid was 100\%, and meropenem, 91.4\%. Highest antimicrobial resistance was found for ampicillin (77.47\%) and moxifloxacin (72.89\%). Nearly $49 \%$ of E. coli strains and $27 \%$ of Klebsiella pneumoniae strains showed extended-spectrum beta-lactamase (ESBL) production. Conclusions: Bacterial UTI persists as one of the most common infections affecting all age groups and both genders. As in other countries, E. coli ranks first in Mexico, with 67.28\%, and nearly 50\% of the strains produce ESBL.
\end{abstract}

KEY WORDS: Urinary tract infections. Antibiotic sensitivity and resistance. Extended-spectrum beta-lactamase-producing bacteria.

\section{Resumen}

Objetivo: Describir la prevalencia, el perfil microbiológico, la resistencia y la sensibilidad a los antibióticos de microorganismos causantes de infecciones de vías urinarias en un centro de referencia de tercer nivel en el occidente de México. Método: Se realizó un estudio transversal que incluyó 5895 urocultivos procesados en el laboratorio de microbiología del 1 de agosto de 2014 al 31 de julio de 2015. Resultados: De los 5895 urocultivos, 3363 correspondieron a mujeres (57.05\%) y 2532 a varones (42.95\%). De los 1444 resultados positivos, se aislaron 1512 microorganismos (prevalencia del 24\%); el más común fue Escherichia coli, con un $67.28 \%$, seguido por Pseudomonas con un $7.12 \%$. Candida glabrata se reportó como el patógeno fúngico más frecuente. De manera general, la sensibilidad a la daptomicina y al linezolid fue del 100\%, y al meropenem fue del 91.4\%. La resistencia más alta se reportó para ampicilina y moxifloxacino (77.47 y $72.89 \%$, respetivamente). Cerca del $49 \%$ y del $27 \%$ de las cepas de E. coli y Klebsiella pneumoniae mostraron producción de betalactamasas de espectro extendido. Conclusiones: Las infecciones de vías urinarias persisten como una de las formas más habituales de infección y afectan a todos los grupos de edad. En México, al igual que en otros países, E. coli se coloca en primer lugar de frecuencia, con el $67.28 \%$.

PALABRAS CLAVE: Infección de vías urinarias. Sensibilidad y resistencia a antibióticos. Bacterias productoras de betalactamasas de espectro extendido.

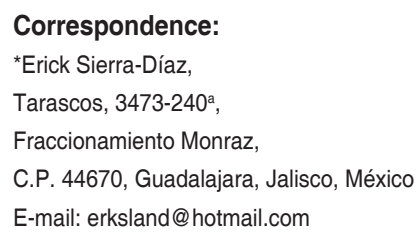

Date of reception: 30-05-2018

Date of acceptance: 14-08-2018

DOI: $10.24875 / C I R U .18000494$
Cir Cir. 2019;87:176-182

Contents available at PubMed www.cirugiaycirujanos.com 


\section{Introduction}

The increasing rate of antibiotic resistance in uropathogens, especially in Escherichia coli and Klebsiella pneumoniae as the most common etiologic agents of urinary tract infections (UTI), leads to difficulties in selecting adequate empirical therapy and achieving treatment success ${ }^{1}$. Since sulfonamide and penicillin were introduced into clinical use in the 1930s and 1940s, respectively, people was motivated by the illusion that infectious diseases were totally controlled by antibiotics. The widespread use of antibiotics, however, imposes strong selection pressure for the development of antibiotic resistance, a major, present-day public health problem ${ }^{2}$. In recent years, the problem has worsened due to the emergence of extended-spectrum beta-lactamases (ESBL), which mediate resistance to $\beta$-lactam antimicrobials, especially the third-generation cephalosporins among these organisms. Genes responsible for ESBL production arise by point mutation at the active site of the earlier $\beta$-lactamases and are usually plasmid mediated. In addition, ESBL-positive and Gram-negative bacteria often carry genes that confer high levels of resistance to many other antibiotics ${ }^{3}$.

A summary of several international surveillance systems that have reported uropathogenic $E$. coli resistance to selected antibiotics in North and South America and Europe reports that there is considerable local variation in resistance. Resistance to ampicillin and trimethoprim ranges from $80 \%$ and $61 \%$ in Mexico to $33 \%$ and $9 \%$ in Quebec. In Mexico, resistance to ciprofloxacin has been reported at $72 \% 4$.

There are many reports in the literature describing the epidemiology of bacterial resistance; however, the microbiologic profile varies from place to place. At our institution, there are no reports on antibiotic resistance and susceptibility trends. The aim of this study was to examine the epidemiological data obtained from isolated bacteria in urine samples from patients at our hospital over a 1-year period. Data included the susceptibility, resistance, and prevalence of ESBL-producing bacteria and fungi.

\section{Methods}

A cross-sectional study was carried out with results from urine samples obtained from hospitalized and outpatients at the Western National Medical Center in Jalisco, Mexico, from August 2014 to July 2015.
Table 1. Etiologic agents

\begin{tabular}{lc}
\hline Microorganism & $\mathbf{n}(\%)$ \\
\hline Isolated bacteria & $1461(96.63)$ \\
Escherichia coli & $983(67.28)$ \\
Pseudomonas & $104(7.12)$ \\
Klebsiella & $94(6.43)$ \\
Enterococcus & $88(6.02)$ \\
Proteus & $45(3.08)$ \\
Staphylococcus & $29(1.98)$ \\
Acinetobacter baumanii & $28(1.92)$ \\
Enterobacter & $25(1.71)$ \\
Morganella morganii & $19(1.30)$ \\
Citrobacter freundii & $18(1.30)$ \\
Providentia & $13(0.89)$ \\
Streptococcus & $7(0.48)$ \\
Others & $8(0.55)$ \\
Isolated fungi & $51(3.37)$ \\
Candida glabrata & $18(35.29)$ \\
Candida albicans & $11(21.57)$ \\
Candida krusei & $9(17.65)$ \\
Trichorosporon beigelli & $8(15.69)$ \\
Others & $4(7.84)$ \\
\hline
\end{tabular}

Samples were processed and analyzed in the Hospital's Microbiology Laboratory. The presence of $\geq 10^{5}$ colony-forming units $/ \mathrm{mL}$ in urine culture (UC) media was considered significant for UTI. Isolated bacteria and antibiotic susceptibility were identified by standard laboratory techniques or an automated system (Vitek, Biomerieux ${ }^{\circledR}$ ) as required.

Inadequate urine samples were excluded from the study: those not processed $1 \mathrm{~h}$ after collection, insufficient urine, or urine that was not well labeled. Results with more than 3 pathogens were also excluded.

The Microsoft Excel ${ }^{\circledR}$ program was utilized to analyze data to obtain demographic data from patients such as gender and age (averages and ranges). The prevalence and percentages of sensitivity and resistance were calculated with basic arithmetic operations. The study was approved by the Institutional Ethics Committee with registration number R-2015-1310-185.

\section{Results}

\section{Demographic characteristics}

A cross-sectional study was conducted with the objective of describing prevalence, microbiological profile, susceptibility, and resistance to antibiotics in UTI. A total of $5895 \mathrm{UC}$ results were collected. Among the results analyzed, 3363 were of women $(57.05 \%)$ and 2532 men (42.95\%). Mean age was 53 years, with a range of 15-102 years. Of the UC performed, $24.5 \%$ ( $n=1444)$ were positive. Based on the total number 
Table 2. Susceptibility to antimicrobials

\begin{tabular}{lcclcc}
\hline Antimicrobial & Total & Susceptible (\%) & Antimicrobial & Total & Susceptible (\%) \\
\hline Daptomycin & 124 & $124(100.00)$ & Cefotaxime & 1335 & $595(44.57)$ \\
Linezolid & 124 & $124(100.00)$ & Cefazolin & 1232 & $543(44.07)$ \\
Meropenem & 1364 & $1247(91.42)$ & Ceftriaxone & 1364 & $599(43.91)$ \\
Imipenem & 1336 & $1220(91.32)$ & Cefuroxime & 1307 & $556(42.54)$ \\
Cefotetan & 1203 & $1092(90.77)$ & Trimethoprim/sulfamethoxazole & 1260 & $467(37.06)$ \\
Vancomycin & 117 & $105(89.74)$ & Synercid & 117 & $43(36.75)$ \\
Amikacin & 1335 & $1163(87.12)$ & Levofloxacine & 1459 & $412(28.24)$ \\
Piperacilin/tazobactam & 1307 & $989(75.67)$ & Amoxicillin/clavulanic acid & 29 & $8(27.59)$ \\
Gentamicin & 1348 & $769(57.05)$ & Moxifloxacin & 1210 & $317(26.20)$ \\
Ticarcilline/clavulanic acid & 1335 & $744(55.73)$ & Ampicillin/sulbactam & 1260 & $330(26.19)$ \\
Cefepime & 1364 & $698(51.17)$ & Ciprofloxacin & 1452 & $374(25.76)$ \\
Aztreonam & 1307 & $582(44.53)$ & Ampicillin & 1327 & $276(20.80)$ \\
Ceftazidime & 1364 & $608(44.57)$ & & &
\end{tabular}

Table 3. Resistance to antimicrobials

\begin{tabular}{lcclcc}
\hline Antimicrobial & Total & Resistant (\%) & Antimicrobial & Total & Resistant (\%) \\
\hline Ampicillin & 1327 & $1028(77.47)$ & Gentamicin & 1348 & $640(47.48)$ \\
Moxifloxacin & 1210 & $882(72.89)$ & Cefepime & 1364 & $649(47.58)$ \\
Ciprofloxacin & 1452 & $1058(72.87)$ & Cefuroxime & 1307 & $617(47.21)$ \\
Amoxicilin/clavulanic acid & 29 & $21(72.41)$ & Ticarcilline/clavulanic acid & 1335 & $203(15.21)$ \\
Levofloxacin & 1459 & $1012(69.36)$ & Vancomycin & 117 & $12(10.26)$ \\
Trimethoprim/sulfamethoxazole & 1260 & $792(62.86)$ & Amikacin & 1335 & $136(10.19)$ \\
Cefazolin & 1232 & $659(53.49)$ & Imipenem & 1336 & $113(8.46)$ \\
Ampicillin/sulbactam & 1260 & $643(51.03)$ & Meropenem & 1364 & $101(7.40)$ \\
Cefotaxime & 1335 & $674(50.49)$ & Piperacilin/tazobactam & 1307 & $75(5.74)$ \\
Ceftriaxone & 1364 & $672(49.27)$ & Cefotetan & 1203 & $37(3.08)$ \\
Aztreonam & 1307 & $623(47.67)$ & Daptomycin & 124 & $0(0.00)$ \\
Ceftazidime & 1364 & $649(47.58)$ & Linezolid & 124 & $0(0.00)$ \\
\hline
\end{tabular}

of patients and the number of positive cases, a prevalence of $24 \%$ was calculated. From 3363 UC performed in women, $25.9 \%(n=872)$ were positive; for the group of men, $22.5 \%(n=572)$ were positive of a total of 2532 UC.

\section{Microbiological profile}

A total of 1512 bacteria and fungi were isolated; two microorganisms were isolated in 68 samples. The most common etiological agent was $E$. coli representing $67.2 \%(n=983)$, and with regard to isolated fungi, Candida glabrata was reported as the most common agent. Table 1 reveals the distribution and percentages of isolated etiologic microorganisms.

Of 1512 isolated pathogens, $96.63 \%$ were bacterial agents $(n=1461)$ and $3.37 \%$ fungi $(n=51)$. Of 1461 isolated bacteria, Escherichia coli showed $67.28 \%(n=983)$ followed by Pseudomonas and Klebsiella. 
Table 4. Susceptibility of antimicrobials for Escherichia coli

\begin{tabular}{|c|c|c|c|c|c|c|c|}
\hline Antimicrobial & $\mathrm{S}(\%)$ & I (\%) & $\mathbf{R}(\%)$ & Antimicrobial & $\mathrm{S}(\%)$ & $\mathrm{I}(\%)$ & R (\%) \\
\hline Imipenem & 99.69 & 0.00 & 0.31 & Ceftriaxone & 48.93 & 1.42 & 49.64 \\
\hline Meropenem & 99.49 & 0.10 & 0.41 & Cefazoline & 45.37 & 1.63 & 53.00 \\
\hline Cefotetan & 97.25 & 0.92 & 1.83 & Tobramycin & 47.30 & 10.17 & 42.52 \\
\hline Amikacin & 95.02 & 2.85 & 2.14 & Cefuroxime & 43.64 & 3.15 & 53.20 \\
\hline Piperacilin/tazobactam & 87.49 & 8.14 & 4.37 & Trimethoprim/sulfamethoxazole & 35.30 & 0.00 & 64.70 \\
\hline Ticarcilline/clavulanic acid & 63.17 & 28.38 & 8.44 & Ampicillin/sulbactam & 23.70 & 24.52 & 51.78 \\
\hline Gentamicin & 56.26 & 0.61 & 43.13 & Levofloxacin & 20.45 & 1.93 & 77.62 \\
\hline Cefepime & 49.95 & 0.00 & 50.05 & Moxifloxacin & 20.45 & 0.71 & 78.84 \\
\hline Cefotaxime & 49.64 & 0.71 & 49.64 & Ciprofloxacin & 19.94 & 0.51 & 79.55 \\
\hline Ceftazidime & 49.44 & 0.10 & 50.46 & Ampicillin & 16.89 & 0.51 & 82.60 \\
\hline Aztreonam & 49.24 & 0.92 & 49.85 & & & & \\
\hline
\end{tabular}

S: sensible, I: intermediate, R: resistant

Table 5. Susceptibility of antimicrobials for Pseudomonas

\begin{tabular}{lccc}
\hline Antimicrobial & $\begin{array}{c}\text { Susceptible } \\
(\%)\end{array}$ & $\begin{array}{c}\text { Intermediate } \\
(\%)\end{array}$ & $\begin{array}{c}\text { Resistant } \\
(\%)\end{array}$ \\
\hline Cefepime & 34.62 & 0.00 & 65.38 \\
Meropenem & 31.73 & 0.96 & 67.31 \\
Imipenem & 26.92 & 0.96 & 72.12 \\
Gentamicin & 25.96 & 1.92 & 72.12 \\
Tobramycin & 25.00 & 0.96 & 74.04 \\
Amikacin & 22.12 & 4.81 & 73.08 \\
Ciprofloxacin & 17.31 & 0.00 & 82.69 \\
Levofloxacio & 17.31 & 1.92 & 80.77 \\
Piperacilin/tazobactam & 2.88 & 88.46 & 8.65 \\
Aztreonam & 0.96 & 32.69 & 66.35 \\
Ceftriaxone & 0.00 & 18.27 & 81.73 \\
Ceftazidime & 0.00 & 31.73 & 68.27 \\
Cefotaxime & 0.00 & 18.27 & 81.73 \\
Ticarcilline/clavulanic acid & 0.00 & 32.69 & 67.31 \\
\hline
\end{tabular}

Table 6. Bacteria producing $\beta$ actamases of extended spectrum

\begin{tabular}{lcc}
\hline Bacteria & $\boldsymbol{n}(\%)$ & Global percentage \\
\hline Escherichia coli & $477 / 983(48.52)$ & 29.07 \\
Klebsiella pneumonie & $23 / 94(27.38)$ & 1.40 \\
Klebsiella oxytoca & $1 / 94(10.00)$ & 0.06 \\
Proteus mirabilis & $2 / 45(4.44)$ & 0.12 \\
\hline
\end{tabular}

Of 51 fungi isolated, C. glabrata was the most common (35.29\%), followed by Candida albicans, Candida krusei, and Trichosporon beigelii.

\section{Sensitivity and resistance to antibiotics}

The sensitivity and resistance of isolated microorganisms were reviewed for 34 antibiotics, highlighting daptomycin and linezolid, both with $100 \%$ sensitivity. Carbapenems were tested in $>1300$ cases, reporting sensitivities of $>90 \%$. Table 2 details the number of tests conducted by antibiotic and sensitivity percentage for the microorganisms.

Similarly, antibiotic resistance was determined. Observed data demonstrated that ampicillin, moxifloxacin, and levofloxacin exhibited resistances in $>70 \%$ in $>1200$ cases. Table 3 reports the details of antibiotic resistance.

As mentioned earlier, E. coli was the most prevalent pathogen. Table 4 lists antibiotic sensitivity and resistance to E. coli.

Pseudomonas aeruginosa was isolated as the second most common pathogen. It was also observed that the sensitivity index was $<35 \%$ for the antibiotics tested. Table 5 records the sensitivity and resistance percentage of antibiotics tested for $P$. aeruginosa, while table 6 registers ESBL-producing bacteria.

\section{Discussion}

Escherichia coli is the most prevalent facultative Gram-negative bacillus among human fecal flora, 
Table 7. Antibiotic resistance in Mexico

\begin{tabular}{|c|c|c|c|c|c|}
\hline Antibiotics & $\begin{array}{c}\text { Molina-Lopez } \\
\text { et } \text { al. }^{7}(n=119)(\%)\end{array}$ & $\begin{array}{c}\text { Paniagua-Contreras } \\
\text { et al. }^{8}(n=194)(\%)\end{array}$ & $\begin{array}{l}\text { Miranda-Estrada } \\
\text { et al. }{ }^{9}(n=107)(\%)\end{array}$ & $\begin{array}{l}\text { López-Banda } \\
\text { et al. } .^{10}(n=108)(\%)\end{array}$ & $\begin{array}{c}\text { Sierra-Diaz } \\
(n=983)(\%)\end{array}$ \\
\hline Ampicillin & 83.70 & 97.4 & 92.5 & 55.7 & 82.6 \\
\hline Ciprofloxacin & 56 & - & 45.8 & 62.3 & 79.5 \\
\hline Moxifloxacin & - & - & - & 52.6 & 78.84 \\
\hline Levofloxacin & - & - & - & 60.2 & 77.62 \\
\hline Trimethoprim/sulfamethoxazole & 56.40 & 66 & 70.1 & 65.1 & 64.7 \\
\hline Cefuroxime & 15 & - & 62.6 & 1.8 & 53.2 \\
\hline Ceftriaxone & 10.20 & 48.9 & 18.7 & 0 & 49.64 \\
\hline Ceftazidime & 9 & - & 57 & 0 & 50.46 \\
\hline Cefotaxime & - & 72.7 & 57 & 0 & 49.64 \\
\hline Cefepime & 7.60 & - & 15.9 & 0 & 50.05 \\
\hline Amikacin & 1.70 & 14.4 & 14 & 6.5 & 2.14 \\
\hline Cefotetan & - & - & - & 1.6 & 1.83 \\
\hline Meropenem & 0.85 & - & - & 0 & 0.41 \\
\hline Imipenem & - & - & - & 1.9 & 0.31 \\
\hline
\end{tabular}

Table 8. Antibiotic resistance in North America

\begin{tabular}{|c|c|c|c|c|}
\hline \multirow[t]{2}{*}{ Antibiotic } & \multicolumn{3}{|c|}{ Foxman $^{4}(\%)$} & \multirow{2}{*}{$\frac{\text { Sierra-Diaz (\%) }}{\text { Mexico }}$} \\
\hline & Canada & USA & Mexico & \\
\hline Ampicillin & 33 & - & 80 & 77.47 \\
\hline $\begin{array}{l}\text { Trimethoprim/ } \\
\text { sulfamethoxazol }\end{array}$ & 9 & - & 61 & 62.86 \\
\hline Quinolones & 0 & $5-10$ & 72 & $71.7^{a}$ \\
\hline
\end{tabular}

usually inhabiting the colon as the innocuous commensal. UTI comprises the most common form of extraintestinal E. coli infection, and E. coli is the most common cause of UTI. At some point during their lives, at least $12 \%$ of men and $10-20 \%$ of women experience an acute symptomatic UTI, and an even greater number develop asymptomatic bacteriuria ${ }^{5}$. The susceptibility of uropathogens to various antibiotics or antibiogram profiling may aid in improving the treatment of UTI without any delay. However, there are many microorganisms responsible for UTI. Among these, some with a high rate of resistant ESBL species have gained much attention ${ }^{6}$. In 2011, Molina-López et al. ${ }^{7}$ analyzed antimicrobial, serotypes, and phylogenetic groups among strains of $E$. coli isolated from outpatients with UTI in Mexico City. Among the 29 identified serotypes, the most frequent was
025: H4 (21.2\%), which has been associated with multidrug resistance and a high virulence potential.

The uropathogenic strains expressed resistance rates as high as $83 \%$ for ampicillin and the lowest resistance rate was for meropenem, with $0.85 \%$. Our work does not identify the serotypes; however, we can add that $67.28 \%$ of isolated bacteria were E. coli, finding the highest index of resistance for ampicillin, with a percentage similar to the resistance reported by Molina-López et al. (83 vs. $82.6 \%)^{7}$. With regard to quinolones and trimethoprim/sulfamethoxazole, our study reported higher resistances.

In another study reported in 2015 by Paniagua-Contreras et al. in Mexico, nearly $48 \%$ of $E$. coli strains were resistant to cephalothin, $97.4 \%$ to ampicillin, and $72.7 \%$ for cefotaxime; of 188 isolated strains, $96.9 \%$ were resistant to at least 3-11 of the antimicrobials studied $^{8}$.

Miranda-Estrada et al. reported, in 2015, an analysis performed on 107 isolates of $E$. coli at two locations in Mexico. Resistance to ampicillin and trimethoprim/ sulfamethoxazole was 92.5 and $70.1 \%$, respectively 9 .

López-Banda et al. analyzed antibiotic resistance in 108 isolated E. coli obtained from 2008 to 2010 in Mexico City. Approximately $20 \%$ of the isolates registered the presence of $\beta$-lactamases. The authors did not report a statistical relationship between multiresistance and phylogenetic group ${ }^{10}$. 
Table 9. E. Coli resistance reported in other countries

\begin{tabular}{|c|c|c|c|c|c|c|c|}
\hline Antibiotics & $\begin{array}{c}\begin{array}{c}\text { Abujnah } \\
\text { et al. }\end{array} \\
\text { (Libya) } \\
(\mathrm{n}=208)(\%)\end{array}$ & $\begin{array}{c}\text { ARESC et al. }{ }^{11} \\
\text { (Europe and } \\
\text { Brazil) } \\
(\mathrm{n}=2315)(\%)\end{array}$ & $\begin{array}{c}\text { Can et al. }{ }^{12} \\
\text { (Turkey) } \\
(n=294)(\%)\end{array}$ & $\begin{array}{c}\text { Sohail et al. }{ }^{13} \\
\text { (Pakistan) }^{(\text {Pa }=244)(\%)}\end{array}$ & $\begin{array}{l}\text { Mamuye } \\
\text { et al. }^{14} \\
\text { (Ethiopia) } \\
(\mathrm{n}=85)(\%)\end{array}$ & $\begin{array}{c}\text { Yilmaz et al. } .^{15} \\
\text { (Turkey) } \\
\text { (n = 8975) (\%) }\end{array}$ & $\begin{array}{c}\text { Sierra-Diaz } \\
(\text { Mexico) } \\
(n=983)(\%)\end{array}$ \\
\hline Ampicillin & 69.2 & 48.3 & - & - & 79.2 & 66.9 & 82.6 \\
\hline Ciprofloxacin & 23.1 & 8.1 & 39 & 82 & 54.7 & 49.9 & 79.5 \\
\hline Levofloxacin & 19.2 & - & - & 82 & - & & 77.62 \\
\hline Trimethoprim/sulfamethoxazole & 37 & 29.4 & 44 & 78 & 22.6 & 20 & 64.7 \\
\hline Cefuroxime & - & 2.4 & 25 & 80 & - & 30.9 & 53.2 \\
\hline Ceftriaxone & 6.7 & - & - & 71 & 45.3 & 28 & 49.64 \\
\hline Ceftazidime & 6.7 & - & - & 71 & - & 14.9 & 50.46 \\
\hline Cefepime & 6.3 & - & - & 71 & - & 12 & 50.05 \\
\hline Amikacin & 0 & - & - & 91 & - & 0.3 & 2.14 \\
\hline Meropenem & 0.5 & - & 0 & 3 & - & 0 & 0.41 \\
\hline Imipenem & 0.5 & - & 0 & 3 & - & 0 & 0.31 \\
\hline
\end{tabular}

Table 10. Uropathogens susceptibility comparison between Mexico and other countries

\begin{tabular}{|c|c|c|c|c|}
\hline Antibiotics & $\begin{array}{c}\text { Mubanga et al. }{ }^{16} \\
\text { (Lesotho) }(n=200)(\%)\end{array}$ & $\begin{array}{c}\text { Stefaniuk et al. }{ }^{17} \\
\text { (Poland) }(n=381)(\%)\end{array}$ & $\begin{array}{c}\text { Osthoff et al. }{ }^{18} \\
\text { (Australia) }(n=200)(\%)\end{array}$ & $\begin{array}{c}\text { Hernandez \& Sierra } \\
\text { (Mexico) }(n=983)(\%)\end{array}$ \\
\hline Ampicillin & - & 38.6 & - & 20.8 \\
\hline Ciprofloxacin & 95.1 & 60.8 & 70 & 25.76 \\
\hline Trimethoprim/sulfamethoxazole & 32.5 & 60.2 & 53 & 37.06 \\
\hline Cefuroxime & - & 82.1 & - & 42.54 \\
\hline Ceftazidime & - & 88.2 & - & 44.57 \\
\hline Cefotaxime & - & 86.5 & - & 44.57 \\
\hline Cefepime & - & 91.1 & - & 51.17 \\
\hline Amikacin & - & 96 & - & 87.12 \\
\hline Meropenem & - & 100 & 100 & 91.42 \\
\hline
\end{tabular}

Table 7 presents the comparison of our work with the aforementioned studies conducted in Mexico.

With regard to data on resistance to antibiotics in North America, Foxman ${ }^{4}$ presented a review in 2010. Table 8 demonstrated the comparison of our study with that reported by Foxman.

The Antimicrobial Resistance Epidemiological Survey on Cystitis study was conducted in nine countries in Europe, as well as in Brazil, to determine the susceptibility of the major uropathogens circulating in the communities of these geographic areas ${ }^{11}$. The authors reported that not all sites exhibited the same susceptibility profile, with some countries less affected by resistance problems than others. In Germany, Hungary, Poland, and the Netherlands, $>90 \%$ of strains were susceptible to fosfomycin, mecillinam, nitrofurantoin, and ciprofloxacin. Susceptibility rates varied widely among countries for ampicillin (32.7-65.5\%), amoxiciIlin/clavulanic acid (51.9-93.5\%), cefuroxime (73-93\%), and trimethoprim/sulfamethoxazole (54.5-87.8\%) ${ }^{12}$.

In terms of $E$. coli bacterial resistance specifically, there are reports from other countries ${ }^{13-15}$. Table 9 shows the analysis and the comparison with our results.

Table 10 compares susceptibility profiles between our results and those of other countries ${ }^{16-18}$ regarding general uropathogens.

Our study sheds light on useful data including those antibiotics such as daptomycin and linezolid may be effective in the treatment of multidrug-resistant cases 
because they exhibited no bacteria resistance. Other medications with a low index of resistance comprised cefotetan, piperacillin/tazobactam, and carbapenems with resistance percentages $<10$. However, it is prudent to analyze the tables of the results obtained in this study at the time of the empirical treatment indicated, due to that the majority of antimicrobial drugs available for oral administration presented resistance percentages of $>50$ for the majority of the pathogens isolated.

\section{Conclusions}

With the described results, it is possible to define an overall panorama of resistance and susceptibility to antibiotics in our working area. This study may also be submitted as a national projection due to the results reported, and it can be concluded that the spectrum of sensitivity and resistance of uropathogenic bacteria to antibiotics coincides partially with those reported by other sources of information at national and international levels. In addition, it is clear that there is more resistance to antibiotics, in general, in our study population, as in other national studies, compared with other countries. Data tables can be useful for the judicious use of antibiotics in our unit.

\section{Conflicts of interest}

The authors declare that they have no conflicts of interest.

\section{Funding}

The author(s) received no specific funding for this work. This work was funded by the Instituto Mexicano del Seguro Social. There was no external funding.

\section{References}

1. Arana DM, Rubio M, Alós Jl. Evolution of antibiotic multiresistance in Escherichia coli and Klebsiella pneumoniae isolates from urinary tract infections: A 12-year analysis (2003-2014). Enferm Infecc Microbiol Clin. 2017;35:293-8.

2. Yoneyama $\mathrm{H}$, Katsumata $\mathrm{R}$. Antibiotic resistance in bacteria and its future for novel antibiotic development. Biosci Biotechnol Biochem. 2006;70:1060-75.

3. Abujnah AA, Zorgani A, Sabri MA, et al. Multidrug resistance and extended-spectrum $\beta$-lactamases genes among Escherichia coli from patients with urinary tract infections in Northwestern Libya. Libyan $\mathrm{J}$ Med. 2015; 10:26412.

4. Foxman B. The epidemiology of urinary tract infection. Nat Rev Urol. 2010;7:653-60.

5. Johnson JR. Virulence factors in Escherichia coli urinary tract infection. Clin Microbiol Rev. 1991:4:80-128.

6. Marialouis XA, Santhanam A. Antibiotic resistance, RAPD-PCR typing of multiple drug resistant strains of Escherichia coli from urinary tract infection (UTI). J Clin Diagn Res. 2016;10:DC05-9.

7. Molina-López J, Aparicio-Ozores G, Ribas-Aparicio RM, et al. Drug resistance, serotypes, and phylogenetic groups among uropathogenic Escherichia coli including O25-ST131 in Mexico city. J Infect Dev Ctries. 2011:5:840-9.

8. Paniagua-Contreras GL, Monroy-Pérez E, Rodríguez-Moctezuma JR, et al. Virulence factors, antibiotic resistance phenotypes and O-serogroups of Escherichia coli strains isolated from community-acquired urinary tract infection patients in Mexico. J Microbiol Immunol Infect. 2017;50:478-85.

9. Miranda-Estrada LI, Ruíz-Rosas M, Molina-López J, et al. Relationship between virulence factors, resistance to antibiotics and phylogenetic groups of uropathogenic Escherichia coli in two locations in Mexico. Enferm Infecc Microbiol Clin. 2017;35:426-33.

10. López-Banda DA, Carrillo-Casas EM, Leyva-Leyva M, et al. Identification of virulence factors genes in Escherichia coli isolates from women with urinary tract infection in Mexico. Biomed Res Int. 2014;2014:959206.

11. Schito GC, Naber KG, Botto H, et al. The ARESC study: An international survey on the antimicrobial resistance of pathogens involved in uncomplicated urinary tract infections. Int J Antimicrob Agents. 2009:34:407-13.

12. Can F, Azap OK, Seref C, et al. Emerging Escherichia coli O25b/ST131 clone predicts treatment failure in urinary tract infections. Clin Infect Dis. 2015;60:523-7.

13. Sohail M, Khurshid M, Saleem HG, Javed H, Khan AA. Characteristics and antibiotic resistance of urinary tract pathogens isolated from Punjab, Pakistan. Jundishapur J Microbiol. 2015;8:e19272.

14. Mamuye $Y$. Antibiotic resistance patterns of common gram-negative uropathogens in St. Paul's hospital millennium medical college. Ethiop J Health Sci. 2016;26:93-100.

15. Yılmaz N, Ağuş N, Bayram A, et al. Antimicrobial susceptibilities of Escherichia coli isolates as agents of community-acquired urinary tract infection (2008-2014). Turk J Urol. 2016;42:32-6.

16. Mubanga $P$, Steinberg WJ, Van Rooyen FC. Antimicrobial susceptibility profile of uropathogens in maluti adventist hospital patients, 2011. Afr J Prim Health Care Fam Med. 2015;7:1-5.

17. Stefaniuk E, Suchocka U, Bosacka K, Hryniewicz W. Etiology and antibiotic susceptibility of bacterial pathogens responsible for community-acquired urinary tract infections in Poland. Eur J Clin Microbiol Infect Dis. 2016;35:1363-9.

18. Osthoff M, McGuinness SL, Wagen AZ, Eisen DP. Urinary tract infections due to extended-spectrum beta-lactamase-producing gram-negative bacteria: Identification of risk factors and outcome predictors in an Australian tertiary referral hospital. Int J Infect Dis. 2015;34:79-83. 